\title{
Growth projections against set-target of renewable energy and resultant impact on emissions reduction in India
}

\author{
Karan Chabhadiya ${ }^{1}$, Rajiv Ranjan Srivastava ${ }^{2^{\dagger}}$, Pankaj Pathak ${ }^{3^{\dagger}}$ \\ ${ }^{1}$ Department of Environmental Science \& Engineering, Marwadi University, Rajkot, Gujarat 360003, India \\ ${ }^{2}$ Center for Advanced Chemistry, Institute of Research and Development, Duy Tan University, Da Nang 550000, Vietnam \\ ${ }^{3}$ Department of Environmental Science, SRM University-AP, Amravati, Andhra Pradesh 522502, India
}

\begin{abstract}
In accordance with the Paris Climate Agreement (COP21) and Sustainable Development Goals (SDGs), India is greatly focused on deployment of renewable energy (RE) for supplementing the energy requirements of the country. The present article assesses the validity of the promises offered by RE technologies in India and its necessary action to understand the gap between setting goals and the ground situation, which can also show a pathway to other developing countries. Therefore, the long-term projection perspectives on RE growth have been made using the India Energy Security Scenario-2047. In order to achieve the set target for emissions reduction of greenhouse gases (GHGs) i.e., $1209 \mathrm{MT} \mathrm{CO}_{2 \mathrm{e}}$ in support of SDGs to the 2005 level by 2030, three renewable growth scenarios have been tested for transitioning the Indian energy system. Accordingly, the regression analysis reveals that the most desirable growth scenario will require a steady rise of RE contribution in the overall energy mix of India by 2030 from the current $\sim 21 \%$ to $68 \%$ of the installed capacity. In this view, the present study highlights the exploration of new alternatives in long-term energy planning, and less on one-sided scenario to achieve the emissions' reduction target.
\end{abstract}

Keywords: Alternative energy, COP21, Greenhouse emissions, Indian energy growth scenario, Sustainable development

\section{Introduction}

India is one of the fastest growing economy and second most populous country in the world. It's energy demand is more than supply, hence threatens energy security and equity consumption [1-3]. Although India shares $7.46 \%$ of the global energy production, the country is facing a plethora of challenges in regard to energy sector, with a doubled consumption of primary energy in recent times [4-6]. The fulfilment of energy demands in India profoundly depends on the coal-based thermal power plants $(\sim 58 \%)$ that exponentially increases the greenhouse gas (GHGs) emissions, while large hydropower projects contribute to $>13 \%$, often causing displacement of a large population and resulting in societal glitches [7, 8]. However, India has large coal reserves but all cannot be used for power generation due to poor fuel grade [9]. This creates a challenging scenario to fulfil the increasing energy demands of the country through the exploitation of finite fossil fuels [7]. It is globally acknowledged that dependence on conventional energy resource causes energy insecurity and catastrophic climate change [10-12]. It overlooks the seventh goal of the United Nations' Sustainable Development Goals (SDGs) for access to affordable, reliable, sustainable, and modern energy for all [13-15]. Therefore, the adoption of alternative energy makes more sense and renewable energy (RE) has been recognized as the most potential substitute for fossil fuels $[16,17]$. RE provides a reliable and secure exposition for the decarbonisation of energy substructure and reduced cradle-to-grave emissions of GHGs $[18,19]$. The potential benefits of RE as shown in Fig. 1 depicts the importance in terms of strengthen socioeconomic scenarios and political stability along with the environmental stewardships and technological up-gradation [20, 21]. Apart from this, the advantages and disadvantages of the major RE resources along with their negative environmental impacts have also been summarized in Table 1. Looking at the need of the hour, India is also taking intensive efforts to secure the energy for future with a great focus on renewable technologies and resources.

Few researchers have analysed the relevance of RE resources in the context of Indian energy sector. Bhide and Monroy (2011) and Schmid (2012) have discussed the issues of energy poverty
This is an Open Access article distributed under the terms of the Creative Commons Attribution Non-Commercial License (http://creativecommons.org/licenses/by-nc/3.0/) which permits unrestricted non-commercial use, distribution, and reproduction in any medium, provided the original work is properly cited.
Received February 14, 2020 Accepted April 07, 2020

${ }^{\dagger}$ Corresponding author

Email: pankajpathak18@gmail.com; r2.srivastava@gmail.com Tel: +91-9726309518 Fax: +08632343000 
Table 1. Advantages, disadvantages, and Potential Environmental Impacts of Each RE Sources

\begin{tabular}{|c|c|c|c|}
\hline $\begin{array}{l}\text { Renewable } \\
\text { source }\end{array}$ & Advantages & Disadvantages & Negative envir \\
\hline Solar & $\begin{array}{l}\text { No air/water pollution (excluding the } \\
\text { background material production works) }\end{array}$ & $\begin{array}{l}\text { May not be cost effective } \\
\text { Back-up and storage are required } \\
\text { Dependent on sunny days }\end{array}$ & $\begin{array}{r}\text { Soil } \\
\text { Landsc } \\
\text { Generation of }\end{array}$ \\
\hline Wind & $\begin{array}{l}\text { Abundantly and freely available } \\
\text { No air/water pollution (excluding the } \\
\text { background material production works) } \\
\text { Less expensive than solar farm }\end{array}$ & $\begin{array}{l}\text { Constant and significant flow of wind } \\
\text { is required } \\
\text { Back-up and storage are required } \\
\text { Significant amount of land is required }\end{array}$ & $\begin{array}{r}\text { Soil } \\
\text { Landsc } \\
\text { Killing of birds } \\
\text { turbil }\end{array}$ \\
\hline Biomass & $\begin{array}{c}\text { Abundantly available } \\
\text { Waste volume reduction after burning } \\
\text { of biomass }\end{array}$ & $\begin{array}{l}\text { Causes air pollution } \\
\text { May not be cost effective due to high } \\
\text { energy-intensive process }\end{array}$ & $\begin{array}{l}\text { Emissions of } \\
\text { Landsc } \\
\text { Generation of }\end{array}$ \\
\hline \multirow[t]{6}{*}{$\begin{array}{l}\text { Small scale } \\
\text { hydroelectric }\end{array}$} & $\begin{array}{l}\text { Abundantly available, clean and safe } \\
\text { Easily storable in reservoirs } \\
\text { Relatively inexpensive }\end{array}$ & $\begin{array}{l}\text { Dams can be built in the limited area } \\
\text { of water flow } \\
\text { Causes floods and landscapes in the } \\
\text { nearby area of dams }\end{array}$ & $\begin{array}{l}\text { Ecological chang } \\
\text { controlling } t \\
\text { Change in } \\
\text { Change in gro }\end{array}$ \\
\hline & \multirow{5}{*}{ Benefits of RE } & \multicolumn{2}{|c|}{$\begin{array}{l}\text { 1. GHG emission reduction. } \\
\text { 2. Increase in environmental values and behaviour. }\end{array}$} \\
\hline & & \multicolumn{2}{|l|}{$\begin{array}{l}\text { 1. Community assets. } \\
\text { 2. Regional development. } \\
\text { 3. Shareholder income. } \\
\text { 4. Community income \& local jobs. }\end{array}$} \\
\hline & & \multicolumn{2}{|c|}{$\begin{array}{l}\text { 1. Renewable energy (RE) education \& training. } \\
\text { 2. RE industry development. } \\
\text { 3. Energy self sufficiency. }\end{array}$} \\
\hline & & \multicolumn{2}{|c|}{$\begin{array}{l}\text { 1. Local ownership \& decision making. } \\
\text { 2. Community building \& empowerment. }\end{array}$} \\
\hline & & \multicolumn{2}{|c|}{$\begin{array}{l}\text { 1. Create actors in renewable powered future. } \\
\text { 2. Build power \& action. } \\
\text { 3. Win hearts \& minds. }\end{array}$} \\
\hline
\end{tabular}

Fig. 1. The potential benefits of the renewable energy $[20,21]$.

in India and concluded that more aggressive promotions of renewable technologies are required as a sustainable solution in the energy mix [22, 23]. By taking the Indian energy scenario unsatisfactory, the scope of $\mathrm{CO}_{2}$ mitigation, development of $\mathrm{RE}$ technologies and their sustainable management have also been studied [24-26]. Further, Garg (2012) has comprehended the potential of RE and suggested $20 \%$ share of renewables in the energy mix till 2020 [27]. Time-to-time, study has been done on the historical development, current scenario, availability of RE, future potentials, and assessment of policy interventions [28-30]. Nonetheless, in most of the cases, the researchers remain selective to particular types of RE in discussion and the newly set target for having an installed capacity of $227.5 \mathrm{GW}$ until 2022 by the means of $113.5 \mathrm{GW}$ solar, 66.5 GW wind, 6.0 GW small hydro, 10.5 GW biomass, others 31.0 GW have never been analysed [31, 32]. Notably, a significant hike of $40 \%$ for the deployment of RE has been proposed by the Government of India (GOI) from the preceding target of 175 GW by 2022, which presents earlier studies in- effective at the current scenario, which may have immense effect to the socioeconomic and political fronts of Indian population and geopolitics as well.

Therefore, the present paper analyses the immutable problems with the conventional fossil fuels, due to which India falls short to meet its energy aspirations for attaining the sustainability in this sector. Then the mathematical models are used to forecast the RE growth and demand projections for future, and thus various demand scenarios have been developed from these forecasts. Furthermore, the paper examines the benefits offered by RE deployments, in accord to meeting the sustainability goals with respect to the growing electricity needs of India. This has been done in two ways: (i) determining the mitigation of the country's import dependence on fossil fuels, and (ii) examining the reduction of GHGs emissions to reach back to the 2005 level i.e., 1209 MT $\mathrm{CO}_{2 \mathrm{e}}$. For this, the database and energy calculator provided by the NITI Ayog (a prime constitution body of Government of India) are used. To make long-term projections on the systematic growth, 
the Indian Energy Security Scenario (IESS), 2047 tool is used to estimate energy scenario. In addition using the regression analysis, three growth scenarios case have been tested for transitioning the Indian energy system, which projects the required contribution of $\mathrm{RE}$ in the future energy mix.

\section{Research Methodology}

The methodology adopted in this review article consists of two-steps: (i) Assessing the database on renewable energy viz., solar, wind, biomass, small-scale hydropower in India, the current status of growing energy sector and their challenges in India, global and indian energy scenario, status-quo of renewable energy in India are used for fetching out the proper data/material for this review article. (ii) The reliable database of Indian scenario was fetched out by the NITI Ayog (a prime constitution body of Government of India) and India Energy Security Scenario (IESS), 2047 to make long-term projections on the systematic growth of RE in India. Using the same platform of IESS-2047, the impact of RE deployment on the Indian economy is also examined to know the country's import dependence on fossil fuels in the energy mix. Further, different case studies based on emissions reduction, mitigation of import dependence of fossil fuels are presented that state the energy flow chart with the maximum clean energy pathways.

\section{Perennial Problems with Conventional Energy}

The world has witnessed a significant energy deficit while relying on conventional sources of energy. Traditionally, coal, oil, and natural gas have remained the major sources of energy. In comparison with the oil and natural gas, coal is abundantly available and widely distributed worldwide; however, other dreadful effects and problems are associated with coal. Firstly, the coal mining and exploration process is not a very eco-friendly practice in itself. Often the coal mines are located in high forest areas, where the mining activities pose a serious threat to the ecosystems. In the next stage, for its usage in thermal power generation, the negative externalities associated with the process are quite serious. For example, typically $1000 \mathrm{MW}$ of gross capacity power plant running with an overall system efficiency of $\sim 43 \%$ would require a coal-feed of 400 tonne per hour (TPH), emitting $800 \mathrm{TPH} \mathrm{CO} 2$ [33]. Global electricity generation data with respect to $\mathrm{CO}_{2}$ emissions are presented in Fig. 2 showing the mammoth contribution of power plants in GHGs emissions [34]. Moreover, it pollutes air due to the emissions of GHGs and suspended particulate matter; water due to waste materials (heavy and hazardous metals) and acid drainage process of coal; and soil by the disposal of ashes and slurry. The aforementioned adversities of coal are the same in any corner of this world, including India, representing coal as a dirty source of energy. Simultaneously, India does not have adequate domestic reserves of oil and natural gas as compared to the country's massive and still growing energy demand. India is fully dependent on import of oil and natural gas demand, and therefore, it is also non-sustainable for the country.

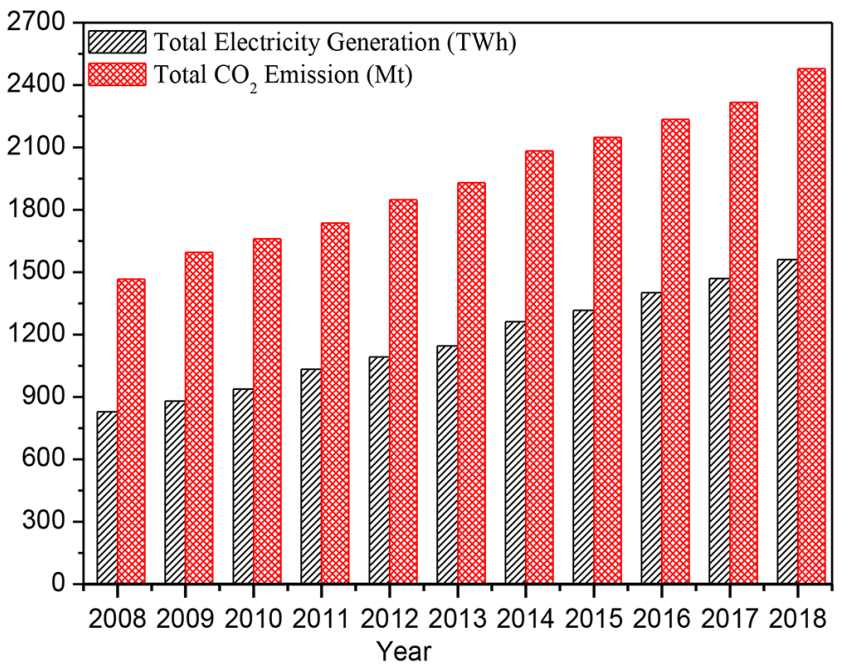

Fig. 2. A worldwide electricity generation and $\mathrm{CO}_{2}$ emissions data [34].

\section{Status-quo and Opportunities for RE Deployment in India}

India, a tropical country is abundantly gifted with different forms of RE natural resources. Solar and wind are particularly having more potential and plenty of sources are available. The annual solar insolation and the major forms of RE installations distributed all over the country are presented in Fig. 3 [35-38].

\subsection{Solar Energy}

Solar energy is the most promising form of RE and has proven technologies solar trough, solar heater, solar panels etc. worldwide. It involves the use of primary energy through the thermal heat-transfer or, to generate electricity as a secondary energy through the solar photovoltaic (SPV) and concentrating solar power (CSP).

\subsubsection{Expansion}

India has high solar insolation due to its location between the Equator and Tropic of Cancer. The average temperature ranging from $25^{\circ} \mathrm{C}$ to $30^{\circ} \mathrm{C}$ with $250-300$ clear sunny days is a favourable condition for higher solar potential [39]. With a daily average solar incident of $4-7 \mathrm{kWh} / \mathrm{m}^{2}$, the total potential for solar energy in India has been estimated as $\sim 750 \mathrm{GW}$. After a slow start with $20 \mathrm{GW}$ solar capacity target in the year 2010, India re-visited its target of solar installation by increasing capacity up to $100 \mathrm{GW}$ within the same timeframe by the year 2022 [40]. Accordingly, India announced to reduce 33-35\% carbon emissions by 2030 from its 2005 level, mainly by increasing the share of non-fossil energy up to a remarkable level (40\%) of the total capacity [41-43]. In this direction, solar-based RE is exemplified through the solar-powered train launched by the Indian Railways, this is the first of its kind in the world where solar photovoltaic (SPV) cell has been used as a power grid in railways [44]. The six-coach train contains $16 \mathrm{SPV}$, each producing $300 \mathrm{Wp}$, Indian Railways has further planned to introduce 50 such coaches in suburban 


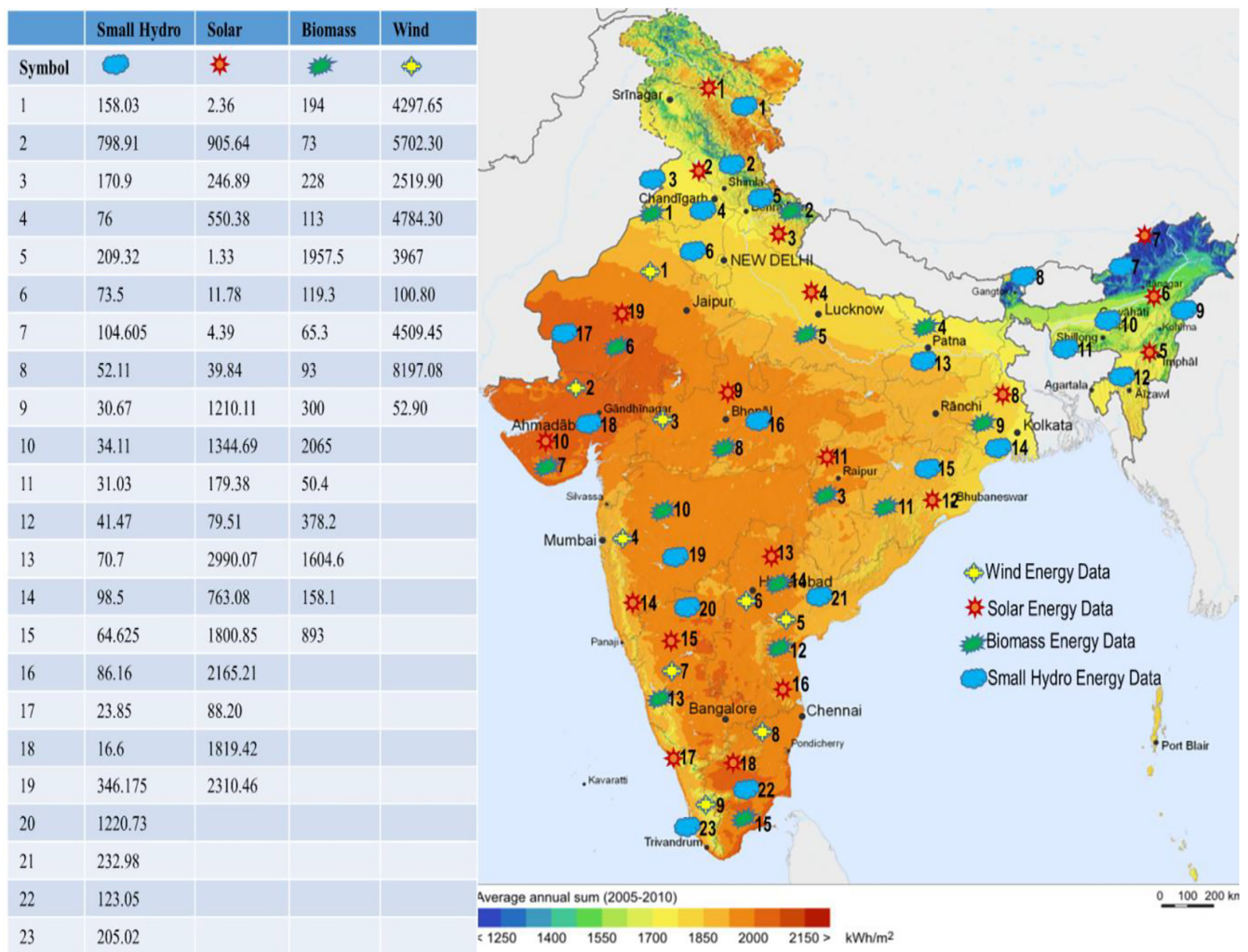

Fig. 3. Pictorial presentation of annual solar insolation along with the major renewable Installations in India.

trains. This would result in an annual saving of 120 million litres of diesel worth INR 6.72 billion, thus ultimately helping to reduce $0.27 \mathrm{Mt} \mathrm{CO}_{2}$ emissions/year. With a capacity of $0.7 \mathrm{MW}$ grid-connected rooftop solar panels, the Guwahati railway station has become the first one to be fully powered by solar energy (saving INR 6.67 million/year). Owing to these benefits, the Indian Railways is further planning to install solar plants at their building rooftops to generate $5000 \mathrm{MW}$ solar energy by 2025 , thereby meeting $25 \%$ of its energy demand [45].

\subsubsection{Challenges}

With the advent of solar growth in India, the sector is growing with the expansion of manufacturing units (9 for solar cells, 22 for PV modules, and 50 for systems manufacturing) under the "Make in India" plan [42]. Concurrently, the large-scale deployment of solar power is hindered by several barriers exist in the current policy, technology, institution, human resources, market, and economy. Some researchers advise for adopting the commercial rooftop projects installation instead of the large-scale solar projects. For example, over 98\% of SPV plants in Germany are decentralized with an ability to generate solar power in close proximity to the consumers [46], eliminating the need of a bigger transmission network. In the context of a growing capacity of RE, the implementation of the large-scale PV projects without having the robust evacuation infrastructure for the transmission lines will prove vital challenging. Although a number of states in India have the potential to become energy surplus through solar energy generation, the stumbling block is in the lack of proper planning for the development of the transmission system. The leading countries in solar energy are investing in $\mathrm{R} \& \mathrm{D}$ and setting up manufacturing facilities for the growth of this sector. India's cell and module manufacturing capacities stand at 1212 MW and 5620 MW, respectively; which corresponds to an average unit size of $86 \mathrm{MW}$ and $69 \mathrm{MW}$, respectively [47] however, these numbers are dwarfed by the multi-GW production in countries like China, USA, Germany, and Malaysia. It infers that a lot has yet to be done in India for the development of solar energy in the technology and policy front as well. A comparison of the important support system provided to the solar manufacturing units is given in Table 2 [48].

The poor efficiency of single junction Si-cells $(\sim 29 \%)$ and screen-printed Si-cells (14-17\%), and the average lifetime efficiency of solar cells (6.3-13\%) are the main technological barriers against the successful implementation of solar projects [49, 50]. Apart from using the SPV, concentrating the large area of solar light into a small beam through a proper source (lenses/mirror/tracking system) for the thermal storage, and subsequent running of a steam turbine can enhance grid flexibility. These concentrated solar power (CSP) systems can have higher steam conversions (i.e., up to $22 \%$ on average) than those using the PV technologies and can be further enhanced by employing a hybrid energy conversion [9]. However, the poor growth of CSP in India is very discouraging. Higher installation and replacement cost, shortage of technical experts, and poor financial strength of the distribution companies are the major concerns in the Indian scenario. Notably, the largest part of the SPV lifetime cost is its capital expenditure. The Central Electricity Regulatory Commission (CERC) has estimated the PV capital cost 
Table 2. A Comparison of Governmental Supports to the Solar Manufacturing Units in Different Countries [48]

\begin{tabular}{lccccc}
\hline Country & Low interest loans & Capital subsidies & R\&D support & Subsidized utilities & Support in acquiring land \\
\hline USA & $\sqrt{ }$ & $\sqrt{ }$ & $\sqrt{ }$ & $\sqrt{ }$ & - \\
China & $\sqrt{ }$ & $\sqrt{ }$ & - & $\sqrt{ }$ & $\sqrt{ }$ \\
India & - & - & - & $\sqrt{ }$ & - \\
Malaysia & $\sqrt{ }$ & $\sqrt{ }$ & $\sqrt{ }$ & $\sqrt{ }$ & $\sqrt{ }$ \\
Taiwan & $\sqrt{ }$ & & & $\sqrt{ }$
\end{tabular}

in India to be INR 69.1 million/MW (for the year 2014-2015), indicating a high up-front investment which requires a longer payback period [51, 52]. The project costs often increase with the multi-window processing system that increases the installation period of the project.

\subsection{Wind Energy}

Wind energy is another major source of RE, having lower life-cycle GHG emissions as compared to solar power [53]. The conversion of wind into its usable form of energy is usually carried out through the wind turbines. Wind turbines, windmills, and wind pumps are a common example of wind energy applications.

\subsubsection{Expansion}

With $6 \%$ of the global installed capacity, India trails behind the global leaders (China, the EU, and the USA having 83\% of global installation) which contribute a major portion of the cumulative wind installed capacity of $487 \mathrm{GW}$ as per 2016 statistics [54]. In order to fulfil the commitment for cleaner energy by 2022, India has identified the potential of wind as an asset for the energy generation [7]. The recent exponential growth in the installed capacity has placed the country at $4^{\text {th }}$ place on the global ranking of wind energy [5, 55, 56]. The growth of wind energy in India is shown in Fig. S1 [14]. As a result of the total installed RE capacity of $102 \mathrm{GW}$, the estimation made in the year 2017 has positively indicated that India is close to attaining its $60 \mathrm{GW}$ target of wind energy production by 2022 [57].

To assess potential wind shears in India, National Institute of Wind Energy has been installed with the establishment of four major wind farm stations located at Jaisalmer in Rajasthan, Jamnagar in Gujarat, Satara in Maharashtra, and Chitradurga in Karnataka [55]. The large coastal area in different states of India can contribute significantly to wind energy generation. Specifically, the Western Ghats region has huge potential due to a long coastline stretch of above $7000 \mathrm{~km}$ with the annual average wind speed of more than $3 \mathrm{~m} / \mathrm{s}$. However, seasonal variation may cause differences in energy generation [42]. For the offshore wind power, the MNRE has set-up medium and long-term goals of $5 \mathrm{GW}$ and $30 \mathrm{GW}$ by the year 2022 and 2030, respectively [6, 32, 55, 58]. Furthermore, it has been reported that offshore wind farms are more efficient over onshore ones, albeit not significantly economical.

\subsubsection{Challenges}

Although the wind energy sector is progressing at a faster rate, plenty of barriers exist similar to those in the solar sector that hinder the widespread installation of wind turbines. The policy, technology, market, economic, human resources and institutional barriers are also crippling this sector [59]. Mone et al. [55] have estimated the construction cost of wind energy to vary from $\$ 57 / \mathrm{MWh}$ to $\$ 85 / \mathrm{MWh}$, and the different parameters of capital costs are dependent on the type of wind power i.e., onshore and offshore [13]. The turbine alone accounts for approximately 51\% of the total cost of the onshore wind energy installation, while the remaining includes $27 \%$ for foundation and installation, $13 \%$ for transmission, $7 \%$ for array cabling and $2 \%$ for miscellaneous expenses. On the other hand, for the offshore wind energy the turbines take up $64 \%$ of the total cost, while rest of the expenses include $16 \%$ for foundation, $11 \%$ for grid connection, and $9 \%$ for planning and secondary expenses [60]. The energy efficiency is not only dependent on cost but also on the types and size of the turbine blades. Thus, the availability of materials critical to the manufacture of wind turbines and energy generation, storage, and transmission is also of vital importance. To get the higher efficiency, the estimated use of approximately $23 \%$ of the global installed capacity until 2015 is based on the advanced PMSG technology [61]. Nevertheless, the use of scarce and energy-critical rare earth metals such as neodymium, praseodymium, dysprosium, and terbium are in high supply-risks, the completion of their service life of 20-25 years will require more such elements to engineer the virgin materials required for renewable energy generation. The unavailability of rare metals in the Indian market poses a serious threat to the future supply of the advanced turbine blade generators.

\subsection{Biomass Energy}

Traditionally being an agrarian economy, India has plenty of biomass which includes, inter alia husk, straw, jute, cotton, coconuts shells, wild bushes, Jatropha plants, and bamboos. The conversion of energy into its useful forms viz., electricity, heat, and biofuels from the biomass, is therefore called biomass energy.

\subsubsection{Expansion}

Broadly the bioenergy contains a complex mix of hydrocarbons derived from plants (living/dead), crops residues, agro waste, and wood industry [62]. In India, biomass energy generation has remained in practice since ancient times in the form of firewood, cow dung, rice husks, and other natural sources. Until now, the traditional biomass remained in use by more than $80 \%$ of the rural and around $15 \%$ of the urban population [63], though the direct burning of biomass has never been considered a safe practice due to the generation of hazardous smoke and ash. As an alternative to the bio/syngas, the biofuels derived from edible sources (such as sugar cane and corn) comes under the first-generation biofuels (refer Fig. S2). The second and third generation biofuels consist of those produced from non-edible sources (e.g., Jatropha and algae) 
while electrofuel and microbiological fuel come under the fourth-generation biofuels [38, 64]. The changes in the field of biomass energy reflected on the policy from time-to-time and are summarized in Table S1 [38, 65]. Traditionally being an agrarian economy, India has adequate amount of biomass hence, there is a huge potential for $30 \mathrm{GW}$ of biomass energy of which $10 \mathrm{GW}$ has been targeted by the year 2022 [38]. Moreover, the new policy implemented in 2016 has made it mandatory to acquire $100 \%$ of the electricity generated by the biowaste plants into the grid. A firm commitment to the usage of biofuels is exemplified by the recent trial of mixing biofuels with aviation fuel. On August 2018, the Indian Institute of Petroleum (CSIR-IIP, Dehradun) successfully tested 25\% biojet fuel in a Spicejet flight from Dehradun to Delhi [66]. In addition, the Ministry of Road Transport and Highways is promoting the usage of vehicles running on either fuel-mix or solely biofuel.

\subsubsection{Challenges}

Despite the biomass availability, bioenergy is still not the preferred RE source, mainly because of uncertainty in the supply chain throughout the year [67]. The agro-based biomass is available only during crop harvesting which consists of around 3 months a year. In this context, the collection, procurement, transportation and storage of biomass are the important factors governing the further use [68]. In absence of a proper supply chain, only $140 \mathrm{Mt}$ out of the total $540 \mathrm{Mt}$ of usable agro-based biomass is currently available for energy production, while rest is being used as cattle fodder and domestic fuel by direct burning. Besides this, some other important factors hindering biomass utilization include the lack of technical expertise, rising cost, and difficulties in capital investment [69]. The specific design of boilers for a particular type of biomass feed is also a hurdle in the expansion of biomass energy production. For example, the replacement of rice husk with bagasse/mustard husk/rice straw would be less efficient due to the higher fuel requirement for a boiler. Some established bioenergy production plants misuse their coal use limit (i.e., 10-15\% of biomass use) to ensure that the power plant remains operational in the lean period of biomass supply. In lacking the mechanized/modern agricultural practices, fragmented land distribution and the rapid increase of biomass price are some other constraints identified by the biomass energy stakeholders. The losses due to the lack of modern agriculture are obvious from the fact that India has more than 11 million hectares of the bamboo area but producing only $\$ 4.5$ billion [70]; while, China produces bamboo worth $\$ 30$ billion in less than 6 million hectares area [71]. Furthermore, the lack of basic collection, transportation and storage systems has forced the farmers in the major agrarian states of India such as Punjab, Haryana, and Uttar Pradesh, to burn their crop residues and agro waste, largely contributing to the deterioration of the air quality and creating smog during the winter season [72]. The aforementioned issues have also been identified as the major cause for the heavy pollution in the New Delhi (national capital of India) and its vicinity, resulting in environmental and health problems [13].

\subsection{Small-scale Hydroelectric Power}

The hydroelectric power is a form of energy derived from the running/flow of water. The flow of water generates energy which is captured and then converted into energy through the turbines. The hydroelectric power generation of capacity from $2 \mathrm{MW}$ to $25 \mathrm{MW}$ (refer Table S2) is considered as a small-scale hydroelectric plant.

\subsubsection{Expansion}

Hydroelectric projects are ideal for managing load variability, meeting the peak requirement and the balancing requirement, arising due to the variability of renewable sources. India has a history of about 110 years of hydroelectric power generation with the first small $130 \mathrm{~kW}$ of a hydro project established in 1897 near the Darjeeling hills in Eastern India [73]. Currently, this scale of power generation comes under the MNRE classification of mini hydroelectric plants, as shown in Table S2 [6].

It is a potential source of RE in India that plays a key role to fight against the climate change issue and reducing the carbon footprint of the power sector. A key benefit of the small hydroelectric plant is the delivery of local energy to the remote communities. Otherwise, they are unlikely to get connected to the main power grid due to high costs in infrastructure set-up. These hydroelectric plants hardly discharge any form of solid, liquid or gaseous wastes into the eco-system, while providing the added advantage of opening up revenues for the economic development of remote and backward regions of the country. Due to such advantages, India has projected $\sim 15,000 \mathrm{MW}$ of small hydroelectric potential, of which about $11 \%$ has been commissioned so far [74].

\subsubsection{Challenges}

Despite the several benefits of small hydroelectric power projects, the establishment of one such project faces manifold problems from the governmental level to resources level as shown in Table S4. Such projects often require getting clearance from the various government departments of road, pollution control, water, environment, forestry and tourism resulting in increased project cost and time. Most of the water sources (rivers) in India are monsoon dependent and hence unreliable due to occasional drought-like situations in summer. The commissioning of more than one power plant along the same stream may cause a cumulative reduction in the performance of electricity generation. Currently, the government offers substantial supportive funds along with the guaranteed purchase of the electricity, and any changes in this policy can damage the future of small hydro projects in India. Besides, the concerns related to civil work design, environmental impact assessment, maintenance, and grid connectivity are the challenges for the success of small hydroelectric projects in the remote areas.

\section{Trends and Projections for RE Deployments}

Generally, the growth and diffusion of new technologies follows S-shaped logistic curve, hence, a simple logistic curve has been used to simulate the RE growth and its forecast in Indian scenario as well, using the Eq. (1):

$$
\mathrm{P}=\frac{\mathrm{L}}{1+\mathrm{Ae}^{-\mathrm{Bt}}} .
$$

where, $\mathrm{P}$ is the cumulative installed capacity at time, $\mathrm{t}$; $\mathrm{L}$ is the saturation level or estimated potential of technology; A is the scaling 
Table 3. Coefficients of Simple Logistic Model for Installed Capacity of Various RE Sources

\begin{tabular}{lccccccc}
\hline \multirow{2}{*}{ RE means } & \multicolumn{3}{c}{ Scenario-1: realistic maximum } & & \multicolumn{3}{c}{ Scenario-2: theoretical maximum } \\
\cline { 2 - 4 } \cline { 6 - 8 } & Coefficient $\boldsymbol{A}$ & Coefficient $\boldsymbol{B}$ & RMSE & & Coefficient $\boldsymbol{A}$ & Coefficient $\boldsymbol{B}$ & RMSE \\
\hline Solar & 1345.5 & 0.45 & 360.99 & 2679.7 & 0.45 & 362.02 \\
Wind & 170.1 & 0.18 & 1108.52 & & 201.7 & 0.17 & 1134.06 \\
Small scale hydropower & 30.6 & 0.11 & 133.98 & & 37.7 & 0.11 & 129.03 \\
Bioenergy & 212.6 & 0.22 & 197.14 & & 139.3 & 0.18 & 219.91 \\
\hline
\end{tabular}

coefficient; and B is coefficient of the internal influence. In the logarithm form, Eq. (2) can be written as:

$$
\ln \left[\left(\frac{L}{P}\right)-1\right]=\ln A-B t
$$

The coefficients A and B have been determined by fitting the model to the data of actual cumulative installed capacity of a given RE technology in India, for the period of 2002-2003 to 2014-2015. The values which minimize the RMSE between the actual cumulative capacity growth and the predicted values from the model are chosen as the best fit values of coefficients A and B. Two different scenarios; (i) realistic maximum, and (ii) theoretical maximum for RE growth in India have been considered. Furthermore, the data gathered from various sources as represented in Table S3 $[6,27,75,76]$ have been fitted to Eq. (2) for the considered scenarios. Based on that the obtained coefficients for the installed capacity of RE (solar, wind, small-scale hydropower, and bioenergy) are shown in Table 3 [33]; whereas, the actual cumulative installed capacity and future prediction under both the realistic and theoretical maximum scenarios are presented in Fig. S3(a)-(d). It can be seen from the results that solar power will attain its saturation level by the year 2035; however, at the present scenario, this seems to be too optimistic. The simple logistic model reflects that the wind power might achieve its saturation level until 2045; small hydropower by 2060; and bioenergy by the year 2040. Nevertheless, it must be noted that all these projections are based on the present estimated potential and trends so far.

Further, using the India Energy Security Scenario (IESS) 2047 prepared by NITI Ayog (a constitutional body of GOI), the energy flow diagrams for the Indian energy system of an integrated scenario are illustrated in Fig. S4 [77]. In which, the development paths in the RE sector is clearly visible. By comparing the energy flow of 2022 (Fig. S4(a)) with 2032 (Fig. S4(b)) and 2047 (Fig. S4(c)), it indicates that the RE connects to the grid will continue to increase after 2022 [77]. Thus, their consumption in different sectors will also increase, more specifically in residential buildings and industrial sector by the year 2047 .

\section{Emissions Reduction of GHGs}

Under the United Nations Framework Convention on Climate Change (UNFCCC) and the Paris Climate Treaty (COP21), India, the worldwide $4^{\text {th }}$ largest emitter of GHGs $\left(\mathrm{CO}_{2 \mathrm{e}}\right)$ has aimed to reduce its $33-35 \%$ emissions by 2030 , primarily by installing its $40 \%$ of electricity capacity from non-fossil fuels $[78,79]$. In order to determine the impact of the GOI initiatives on the GHGs emissions, a regression analysis of the energy generation and $\mathrm{CO}_{2 \mathrm{e}}$ emissions within the timeframe of the year 2005-2016 is carried out using the data obtained from BP statistical review (2019) [34], yielding the relationship as presented below:

$$
\mathrm{CO}_{2(t)}=1534.8 \times \ln \mathrm{EG}-8858.7
$$

where $\mathrm{CO}_{2}$ emission is in million tonne (MT) and EG is energy generation in million tonne oil equivalent $\left(\mathrm{MTO}_{\mathrm{e}}\right)$ for a particular year, $t$. Three different scenarios have been anticipated in the Indian energy sector and the contributed emissions have been calculated for each case.

Case-I is assumed for 10-20\% RE growth from the year 2018 to 2020 , thereby a constant $25 \% \mathrm{RE}$ growth is expected for the total energy demand up to 2035. In this case, the conventional energy sector would be having an equal contribution to the energy generation without any decline. The results based on this assumption are presented in Fig. 4, reflecting no benefit in terms of emissions reduction. It indicates that the consistent growth in $\mathrm{GHGs}\left(\mathrm{CO}_{2 \mathrm{e}}\right)$ emissions with respect to the energy generation cannot be taken as the sustainable pathway.

However, the Case-II is assumed for the same pace of RE growth by $10-20 \%$ in between the year 2018 to 2020, and then it will increase by the expected growth of $25 \%$ until 2035. Notably, it is expected that India would go for 13\% energy mix (including conventional and renewable) by 2022 [52]. Thus, it is anticipated that RE will replace the conventional (thermal) energy by $5 \%$ for

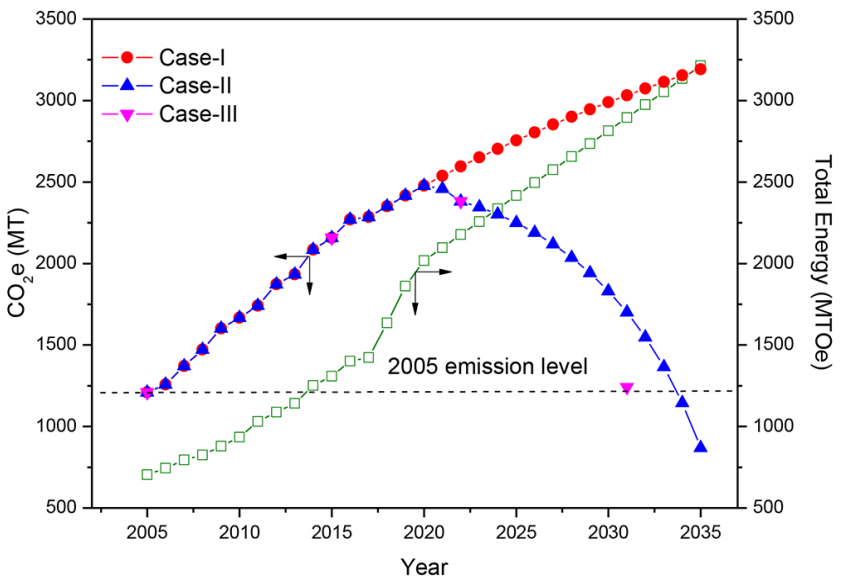

Fig. 4. Different scenarios for contributed emissions of GHGs with the total energy demand with time. 
the year 2021 and further 13\% RE mix contribution from 227.5 GW of installed capacity by 2022. Moreover, it is also projected that RE mix would be increasing at yearly rate of $5 \%$, whilst no new capacity build-up is projected by the thermal power plant till 2027. The results based on Case-II assumption are presented in Fig. 4 shows a remarkable reduction in emissions albeit the consistent growth in total energy generation. The emission is found to decrease from 2157 MT to 1830 MT of $\mathrm{CO}_{2 \mathrm{e}}$ within 15 years of timeframe starting from 2015. Although this reduction of GHGs emissions by India will not be reaching to that of the committed level of 2005 (in accord to the COP21), the significant decline in emissions can certainly be taken as the sustainable move towards the mitigation of climate change scenario.

The target made by GOI in COP21 to cut down the emissions to 2005 level $1209 \mathrm{MT} \mathrm{CO}_{2 \mathrm{e}}$ by 2030, that is recommended by the Case-III presented in Fig. 4. In order to meet this optimistic target, the data coming out by the regression analysis tells for the requirement of a huge $68 \%$ RE to the energy mix. By which, the emissions can bring down to $1240.4 \mathrm{MT} \mathrm{CO}_{2 \mathrm{e}}$ by 2030, reaching an equivalent to the emissions level of 2005. At the present scenario, the $68 \%$ RE seems to be hypothetical and too optimistic to accomplish. To achieving the target in this figure would be very difficult, even after India achieves to build the capacity of 227.5 GW renewables by 2022. Such a projection clearly indicates more brainstorming in this issue, and the requirements of a multi-dimensional approach to control the GHGs emissions, parallel to the aggressive deployment of RE.

\section{Recommendations}

The aforementioned analysis indicates that India has significant potential on the renewable fronts if correctly directed to manage its resources. Therefore, sizeable chunk is to be done by the policymakers and engineers for future energy planning to meet the energy aspiration of the country. To meet the promises of COP21 for the emissions reduction to 2005, India should work on multi-dimensional ways. It needs to explore all the possibilities to control the capital and operational costs with a simultaneous increase in energy production capacities. The dependency on RE through capacity addition by large-scale concentrating solar power plants cannot be taken as sustainable. Despite the benefits of concentrating power at one place, high distribution costs due to long transmission lines and far-located transformer stations cannot be ignored. In between the regional diversity and hard to reach remote locations of India, the mini/microgrids with decentralized energy production would be more helpful due to their low expenditure on infrastructure. Moreover, the existence of a large number of un-electrified rural households, loss of power during transmission and distribution and poor grid connectivity can be appropriately handled by promoting the decentralized power generation. Henceforth, a shift in policy is much required by considering the global trends and the specific requirements of India, along with the new R\&D and implementation of novel technologies.

The incentives and subsidies provided by the government are additionally required not only to support the establishment of new $\mathrm{RE}$ set-ups but also for the development of new technologies in

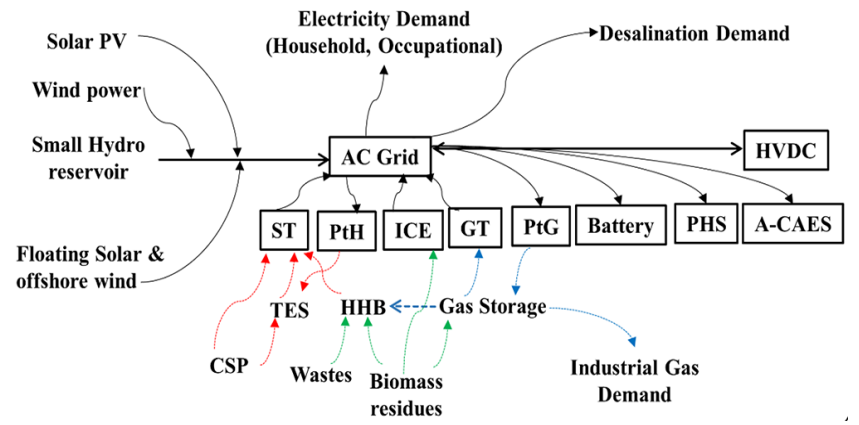

Fig. 5. A recommended integrated grid model of energy mix for Indian scenario (CSP-Concentrated solar power; GT- Gas turbine; HHBHot heat burner; ICE- Internal combustion engine; PtHPower-to-heat; PtG- Power-to-gas; PV- Photovoltaic; ST-Steam turbine).

this area. A push for the indigenous manufacturing of critical materials to RE is required to accelerate for matching the current demand of RE (227.5 GW) by March 2022. Moreover, a comprehensive management system and the legislation for the end-of-life materials can significantly contribute.

To ensure the overall sustainability in the energy sector, India must explore all the possibilities for RE integration with the conventional power plants. Energy production through the plenty available biomass such as bamboo and the agro-waste from the remote and geographically challenging areas of North-Eastern India (which account for $28 \%$ of the total bamboo area of the country) can be a power booster to fulfil the existing and future local energy requirements.

The natural patterns of wind and water supply for small and mini scale power plants, the biomass supply during the off-season for crop harvesting time and availability of sunlight during monsoon season, are highly fluctuating in India. Therefore, the integrative energy plan can narrow the burgeoning demand-to-supply gap. A typical integrative model of such an energy mix in the Indian scenario is suggested in Fig. 5. As it has been mentioned that India has revised the RE deployment plan from $175 \mathrm{GW}$ to 227.5 GW, a contribution of $14 \%$ SPV, $20 \%$ CSP, $20 \%$ wind power, $2 \%$ small-hydroelectric power, $9 \%$ floating solar and offshore wind energy, and 3\% bioenergy will require to meet COP21 promise of RE utilization by 2030 with the proposed energy mix. It is also notable that this renewable mix excludes the contribution of large hydropower, whose contribution should be of $32 \%$ in the proposed energy mix model to achieve the target in accord with COP21.

\section{Conclusions}

The present work identifies the potential of growth and reduction of GHGs emissions in order to meet the aspirations for $227.5 \mathrm{GW}$ of renewable energy in India by the year 2022. The mathematical model used for RE projections in Indian context reveals for attaining the saturation level of solar, wind, small hydropower, and bioenergy by the year of 2035, 2045, 2060, and 2040, respectively. The energy flow diagrams for long-term projections of an integrated scenario illustrate that the developments in RE sector connected to the 
grid system will significantly contribute from 2022 to the year 2047. With the new capacity building target, a steady growth of $\mathrm{RE}$ from $21.4 \%$ to $68 \%$ of the installed capacity will be required. A significant decline in GHGs emissions to $1240.4 \mathrm{Mt} \mathrm{CO}_{2 \mathrm{e}}$ (the emissions level of 2005) has found to be achievable by 2030 albeit seems to be hypothetical at the present scenario. The analysis of different scenarios shows that though the present renewable resources can provide a sizeable chunk of the future electricity demand in country, but it would not be sufficient for the Indian energy policy. Exploration of new alternatives, dedicated research, path-breaking engineering are indispensable for the cause of sustainable energy sufficiency in India.

\section{Acknowledgment}

Authors are thankful to their colleagues for their valuable inputs during the preparation of this manuscript. Moreover, the authors declare that this research work did not receive any specific grant from funding agencies in the public, commercial, or not-for-profit sectors.

\section{Author Contributions}

K.C. (M.Tech student) led on reviewing and analyzing the literature and K.C. and R.R.S (Ph.D) provided background data to perform the statistical analysis by P.P. (Ph.D). P.P. and K.C. wrote the initial version of paper for redrafting with inputs from R.R.S.

\section{References}

1. Pathak P. An Assessment of Strontium Sorption onto Bentonite Buffer Material in Waste Repository. Environ. Sci. Pollut. Res. 2017;24:8825-8836.

2. Rogge KS, Dutschke E. What makes them believe in the low-carbon energy transition? Exploring corporate perceptions of the credibility of climate policy mixes. Environ. Sci. Policy. 2018;87:74-84.

3. Srivastava RR, Pathak P, Perween M. Environmental and health impact due to uranium mining, in: Gupta, D.K., Walther, C. (Eds.), Uranium in Plants and the Environment. Springer Nature, Switzerland, 2020:69-89.

4. Ellabban O, Abu-Rub H, Blaabjerg F. Renewable energy resources: Current status, future prospects and their enabling technology. Renew. Sustain. Energy Rev. 2014;39:748-764.

5. India Energy Outlook 2015. International Energy Agency (2015). [cited 5 March 2019]. Available from: https://www.iea.org/.

6. Ministry of New and Renewable Energy (2018). [cited 10 November 2019]. Available from: https://mnre.gov.in.

7. BP Statistical Review, BP Statistical Review of World Energy Report 1965-2015 (2017) [cited 11 January 2020]. Available from: https://www.bp.com/content/dam/bp/en/corporate/pdf/ energy-economics/statistical-review-2017/bp-statistical-review-of-world-energy-2017-full-report.pdf.

8. Sharma NK, Tiwari PK, Sood YR. Solar energy in India:
Strategies, policies, perspectives and future potential. Renew. Sustain. Energ. Rev. 2012;16:933-941.

9. Bhushan C, Kumarankandath A, Goswami N. 2015. The state of concentrated solar power in India: a roadmap to developing solar thermal technologies in India, Centre for Science and Environment, New Delhi [cited 24 December 2019]. Available from: http://www.cseindia.org/userfiles/State\%20of\%20CSP\% 20in\%20India\%20low.pdfo

10. Coker P, Barlow J, Cockerill T, Shipworth D. Measuring significant variability characteristics: an assessment of three UK renewables. Renew. Energ. 2013;53:111-120.

11. O’Mahonv T, Dufour J. Tracking development paths: Monitoring driving forces and the impact of carbon-free energy sources in Spain. Environ. Sci. Policy. 2015;50:62-73.

12. Sobri S, Koohi-Kamali S, Rahim NA. Solar photovoltaic generation forecasting methods: A review. Energ. Convers. Manage. 2018;156:459-497.

13. Liu Q, Lei Q, Xu H, Yuan J. China's energy revolution strategy into 2030. Res. Conserv. Recyc. 2018;128:78-89.

14. Pujara Y, Pathak P, Sharma A. Govani J. Review on Indian Municipal Solid Waste Management Practices for Reduction of Environmental Impacts to achieve Sustainable Development Goals. J. Environ. Manage. 2019;248:109238.

15. UNSDG, United Nations Sustainable Development Goals (2015) [cited 25 December 2019]. Available from: https://www.un.org/ sustainabledevelopment/sustainable-development-goals/.

16. Schmidt J, Gruber K, Klingler M, et al. A new perspective on global renewable energy systems: why trade in energy carriers matters. Energ. Environ. Sci. 2019;12:2022-2029.

17. Yuan XC, Lyu YJ, Wang B, Liu QH, Wu Q. China's energy transition strategy at the city level: The role of renewable energy. J. Clean. Prod. 2019;205:980-986.

18. Garcia-Olivares A, Sole J, Osychenko O. Transportation in a 100\% renewable energy system. Energy. Convers. Manage. 2018;158:266-285.

19. Ramos A, Chatzopoulou MA, Guarracino I, Freeman J, Markides CN. Hybrid photovoltaic-thermal solar systems for combined heating, cooling and power provision in the urban environment. Energ. Convers. Manage. 2017;150:838-850.

20. Fridahl M, Lehtveer M. Bioenergy with carbon capture and storage (BECCS): Global potential, investment preferences, and deployment barriers. Energ. Res. Soc. Sci. 2018;42:155-165.

21. Overland I. The geopolitics of renewable energy: Debunking four emerging myths. Energ. Res. Soc. Sci. 2019;49:36-40.

22. Bhide A, Monroy CR. Energy poverty: a special focus on energy poverty in India and renewable energy technologies. Renew. Sustain. Energ. Rev. 2011;15:1057-1066.

23. Schmid G. The development of renewable energy power in India: which policies have been effective? Energ. Policy. 2012;45:317-326.

24. Jha SK, Puppala H. Prospects of renewable energy sources in India: Prioritization of alternative sources in terms of Energy Index. Energy 2017;127:116-127.

25. Panwar NL, Kaushik SC, Kothari S. Role of renewable energy sources in environmental protection: A review. Renew. Sustain. Energ. Rev. 2011;15:1513-1524.

26. Shrimali G, Konda C, Farooquee AA. Designing renewable en- 
ergy auctions for India: Managing risks to maximize deployment and cost-effectiveness. Renew. Energ. 2016;97:656-670.

27. Garg P. Energy scenario and vision 2020 in India. J. Sustain. Energ. Environ. 2012;3:7-17.

28. Bekun FV, Alola AA, Sarkodie SA. Toward a sustainable environment: Nexus between $\mathrm{CO}_{2}$ emissions, resource rent, renewable and nonrenewable energy in 16-EU countries. Sci. Total Environ. 2019;657:1023-1029.

29. Reddy VS, Kaushik SC, Panwar NL. Review on power generation scenario of India. Renew. Sustain. Energ. Rev. 2013;18:43-48.

30. Vishnupriyan J, Manoharan PS. Multi-criteria decision analysis for renewable energy integration: A southern India focus. Renew. Energ. 2018;121:474-488.

31. Khan A. 2018. Government eyes 225 GW renewable energy by 202. [cited 10 January 2020]. Available from: http:/ www.newindianexpress.com/business/2018/jun/06/government-eyes-225-gw-renewable-energy-by-2022-1824290.html.

32. Saluja N, Singh S. 2018. Renewable energy target now 227 GW, will need $\$ 50$ billion more in investments. [cited 12 December 2019]. Available from: https://economictimes. indiatimes.com/industry/energy/power/india-will-add-225gwrenewable-energy-project-capacity-by-2022-r-k-singh/articleshow/ 64461995.cms.

33. Singh R. Energy sufficiency aspirations of India and the role of renewable resources: Scenarios for future. Renew. Sustain. Energ. Rev. 2018;81:2783-2795.

34. BP Statistical Review, 2019. BP statistical review of world energy, 68 ${ }^{\text {th }}$ Edition (2019). [cited 10 January 2020]. Available from: https:/www.bp.com/content/dam/bp/business-sites/en/global/ corporate/pdfs/energy-economics/statistical-review/bp-statsreview-2019-full-report.pdf.

35. Akhatar S. 2018. Government of India Ministry of New and Renewable Energy. (accessed 15 November 2019]. Available from: https://www.icds-wcd.nic.in/nnm/Events/National Workshop/ MNRE_NW_20-03-2019.pdf .

36. EnergyNext. 2017. Small Hydro Power in India. [cited 18 November 2019]. Available from: http://www.energynext. in/2017/03/smallhydro-power-in-india.

37. IWPC, 2018. India Wind Power Capacity. [cited 20 November 2019]. Available from: http://www.indianwindpower.com/ pdf/Statewise-Installed-Capacity.pdf.

38. Power from Renewables. 2018. [cited 16 December 2019]. Available from: https://mnre.gov.in/file-manager/annual-report/2017-2018/EN/pdf/chapter-3.pdf.

39. Ansari MF, Kharb RK, Luthra S, Shimmi SL, Chatterji S. Analysis of barriers to implement solar power installations in India using interpretive structural modelling technique. Renew. Sustain. Energ. Rev. 2013;27:163-174.

40. MNRE 2015. Ministry of New and Renewable Energy Annual report. [cited 10 November 2019]. Available from: http://www. mnre.gov.in/reports/2015.

41. Ramachandra TV, Aithal BH, Sreejith K. GHG footprint of major cities in India. Renew. Sustain. Energ. Rev. 2015;44:471-495.

42. Sen S, Ganguly S, Das A, Sen J, Dey S. Renewable energy scenario in India: Opportunities and challenges. J. African Earth Sci. 2016;122:25-31.

43. VC Circle 2015. India commits $33-35 \%$ cut in carbon intensity by 2030. [cited 5 January 2020]. Available from: https:/ www.vccircle.com/india-commits-33-35-pc-cut-carbon-intensity-2030-0/.

44. The Economic Times. Indian Railways launches first solar-powered train. 2017. [cited 19 December 2019]. Available from: https://economictimes.indiatimes.com/industry/transportation/railways/indian-railwayslaunches-first-solar-poweredtrain/huge-savings/slideshow/59593825.cms.

45. Sushma UN. 2018 India now has a railway station that's fully powered by solar energy. [cited 19 December 2019]. Available from: https://qz.com/india/1280526/guwahati-is-indias-first-fullysolar-powered-railwaystation/.

46. Wirth W. Recent facts about photovoltaics in Germany 2015. Fraunhofer Institute for Solar Energy Systems ISE. [cited 11 January 2020]. Available from: https://www.ise.fraunhofer. de/en/publications/veroeffentlichungen-pdf-dateienen/studienund-konzeptpapiere/recent-factsabout-photovoltaics-in-germany. pdf

47. Rathore PKS, Rathore S, Singh RP, Agnihotri S. Solar power utility sector in India: Challenges and opportunities. Renew. Sustain. Energ. Rev. 2018;81:2703-2713.

48. Energetica India 2015. Solar Manufacturing in India; A KMPG Report. [cited 18 December 2019]. Available from: http://www.energetica-india.net/download.php?seccion=articles\&archivo= 3Eksv7L8BosildPLOdK84G1zZk6Ew1co6BVp8hm0LThwxw9 APH9HOx8.pdf.

49. Bhandari KP, Collier JM, Ellingson RJ, Apul DS. Energy payback time (EPBT) and energy return on energy invested (EROI) of solar photo voltaic systems: a systematic review and meta-analysis. Renew. Sustain. Energ. Rev. 2015;47:133-141.

50. Hsu CH, Lin YP, Hsu HJ, Tsai CC. Enhanced spectral response by silicon nitride index matching layer in amorphous silicon thin-film solar cells. J. Non-Cryst. Solids. 2012;358:2324-2326.

51. Central Electricity Authority, annual reports 2016. [cited 2 December 2019]. Available from: http://www.cea.nic.in/reports. html.

52. IREDAL, 2017. Indian Renewable Energy Development Agency Limited. [cited 16 November 2019]. Available from: http://www.ireda.gov.in/forms/contentpage.aspx?lid=740.

53. Amponsah NY, Kington B, Hough RL. Greenhouse gas emissions from renewable energy sources: a review of lifecycle considerations. Renew. Sustain. Energ. Rev. 2014;39:461-75.

54. Bento N, Fontes M. Emergence of floating offshore wind energy: Technology and industry. Renew. Sustain. Energ. Rev. 2019;99:66-82.

55. Mone C, Hand M, Bolinger M, Rand J, Heimiller D, Ho J. 2017. A technical report on 2015 cost of wind energy, review. National Renewable Energy Laboratory 1-115. [cited 11 December 2019]. Available from: https://www.nrel.gov/docs/fy17osti/66861.pdf.

56. NITI Aayog 2017. Government of India, Draft National Energy Policy. [cited 15 December 2019]. Available from: https:// niti.gov.in/writereaddata/files/new_initiatives/NEP-ID_27. 06.2017.pdf.

57. Manju S, Sagar N. Progressing towards the development of sustainable energy: A critical review on the current status, applications, developmental barriers and prospects of solar photovoltaic systems in India. Renew. Sustain. Energ. Rev. 
2017;70:298-313.

58. Offshorewind.biz., 2018. India Sets 2022 and 2030 Offshore Wind Targets. [cited 16 December 2019]. Available from: https://www.offshorewind.biz/2018/06/19/india-sets-2022and-2030-offshorewindtargets/.

59. Freiberg A, Schefter C, Girbig M, Murta VC, Seidler A. Health effects of wind turbines on humans in residential settings: Results of a scoping review. Environ. Res. 2019;169:446-463.

60. IRENA 2018. Renewable Power Generation Costs in 2017. [cited 18 December 2019]. Available from: https://www.irena.org/-/media/Files/IRENA/Agency/Publication/ 2018/Jan/IRENA_2017_Power_Costs_2018.pdf.

61. Blagoeva D, Alves DP, Marmier A, Pavel CC. 2016. Assessment of the potential bottlenecks along the materials supply chain for the future deployment of low-carbon Energy and transport technologies in the EU; Joint Research Centre (JRC). Publications Office of the European Union. EUR 28192 EN. Available from: http://dx.doi.org/10.2790/08169.

62. Balezentis T, Streimikiene D, Zhang T, Liobikiene G. The role of bioenergy in greenhouse gas emission reduction in EU countries: An Environmental Kuznets Curve modelling. Res. Conserv. Recyc. 2019;142:225-231.

63. Kumar A, Kumar K, Kaushik N, Sharma S, Mishra S. Renewable energy in India: Current status and future potential. Renew. Sustain. Energ. Rev. 2010;14:2434-2442.

64. Depra MC, Santos AMD, Severo IA, Santos AB, Zepka LQ, Jacob-Lopes E. Microalgal Biorefineries for Bioenergy Production: Can We Move from Concept to Industrial Reality?. Bioenerg. Res. 2018;11:727-747.

65. Mittal S, Ahlgren EO, Shukla PR. Barriers to biogas dissemination in India: A review. Energy Policy. 2018;112:361-370.

66. The Economic Times. 2018 Spice Jet operates India's first biofuel-powered flight from Dehradun to Delhi. [cited 5 November 2019]. Available from: https://economictimes.indiatimes.com/ industry/transportation/airlines-/-aviation/spicejet-operatesindias-first-biojet-fuel-flight/articleshow/65560105.cms.

67. Sorrell S. Reducing energy demand: A review of issues, challenges and approaches. Renew. Sustain. Energ. Rev. 2015;47:74-82.

68. Jensen JP, Skelton K. Wind turbine blade recycling: Experiences, challenges and possibilities in a circular economy. Renew. Sustain. Energ. Rev. 2018;97:165-176.

69. Srivastava R. 2012. Bio Energy in India: Issues and Challenges. [cited 20 December 2019]. Available from: http://www. greenworldinvestor.com/2012/12/11/bio-energy-in-india-issues-and-challenges.

70. India State of Forest Report (ISFR) 2017. Bamboo Resources of the Country. [cited 20 December 2019]. Available from: http://fsi.nic.in/isfr2017/isfr-bamboo-resource-of-the-country2017.pdf.

71. Song X, Zhou G, Jiang H, et al. Carbon sequestration by Chinese bamboo forests and their ecological benefits: assessment of potential, problems, and future challenges. Environ. Rev. 2011;19:418-428.

72. Sharma V. 2018. Penalise those burning crop residue stubble: Economic Survey. [cited 19 December 2018]. Available from: https://www.tribuneindia.com/news/nation/penali s e - th o s e - b u r n i n g - c r o p - r e s i d u estubble-economic-survey/535533.html.

73. Erlewein A, Nusser M. Offsetting Greenhouse Gas Emissions in the Himalaya? Clean Development Dams in Himachal Pradesh, India. Mountain. Res. Develop. 2011;31:293-304.

74. Oza, M., 2015. Government launches National Mission on Small Hydro, Hydro power, Energetica India. [cited 16 December 2018]. Available from: wckDfYtCwmXW8XvdC9HC87MC7 s3k4oYoF0slXanIBAe9YPbaMicJepM\%20(1).pdf.

75. Ramesh, M., 2015. Wind power installations marginally up in 2014-15. Business Line, The Hindu. [cited 15 December 2019]. Available from: http://www.thehindubusinessline.com/ companies/wind-power-installations-marginally-up-in201415/article7078015.ece.

76. Ramesh, M., 2018. Solar power installed capacity crosses 4 GW-milestone. Business Line, The Hindu. [cited 15 December 2019). Available from: http://www.thehindubusinessline.com/ economy/macro-economy/solar-installations-in-india-crossthe-4-gwmark/article7603722.ece.

77. India Energy Security Scenario (IESS)-2047 (2019). [cited 5 December 2019]. Available from: http://iess2047.gov.in/pathways/2220222222222222022222222201222220222222221120 2220222022222/sankey\#.

78. Akashi O, Hanaoka T. Technological feasibility and costs of achieving a $50 \%$ reduction of global GHG emissions by 2050: mid- and long-term perspectives. Sustain. Sci. 2012;7:139-156.

79. Su X, Shiogama H, Tanaka K, et al. How do climate-related uncertainties influence 2 and $1.5^{\circ} \mathrm{C}$ pathways? Sustain. Sci. 2018;13:291-299. 